\title{
India in the Indo-Pacific
}

\author{
Prof Manish \\ Dean, School of International Studies, Central University of Gujarat, Gandhinagar -Gujarat, India
}

\begin{abstract}
:
With the global power axis shifting away from the Pacific-Atlantic to the Indo-Pacific region, new power alliances seem to be emerging, and New Delhi wants to play a greater role in shaping it. With the rapid expansion of trade, investment and production linkages in the area spanning the Indian and Pacific Ocean regions, it has given rise to what is now known as the Indo-Pacific geo-strategic arc. Geospatially, the Indo-Pacific, spreading from India to the Western Pacific, is the home to over 3.5 billion people, the combined GDP of over \$20 trillion. The region signifies a combination of Asia-Pacific and the Indian Ocean Rim countries. It also has three of the four largest economies in the world, i.e. China, Japan and India. The Indian Ocean holds two maritime trade gateways: The Strait of Hormuz and the Strait of Malacca- and has around 85 percent of the world's maritime trade, primarily oil passing through it. Moreover, 65 percent of the world's oil reserves belong to just 10 of the Indian Ocean littoral states. With China's rise in Asia, and its expanding footprints in the Indian Ocean, the region is likely to face major security challenges. The most likely China challenge in Indo-Pacific is that of the security of the Sea Lanes of Communications (SLOCS). This has raised significant concerns for other major regional players such as India, Japan, and the United States, prompting new partnerships among the major countries, given their convergence of interests in the Indo-Pacific security architecture. The United States wants to re-balance its Asia strategy. Japan, Indonesia, Singapore and Australia have also gone to the extent of formulating the Indo-Pacific concept in their official lexicon. How is today's concept of Indo-Pacific different from the earlier concepts of Asia-Pacific? Is "Indo-Pacific" space the new theatre of 'rivalry' between the United States -China and China- India? What are India's interests in promoting the idea of Indo-Pacific?
\end{abstract}

Key words: Asia, Indo-Pacific, Security architecture, India, United States, Japan, Australia, China 